Social Institutions and Economic Development

A Tribute to Kurt Martin 


\title{
Social Institutions and Economic Development
}

\author{
A Tribute to Kurt Martin
}

\author{
edited by \\ Valpy FitzGerald \\ University of Oxford, United Kingdom \\ and Institute of Social Studies, The Hague, The Netherlands
}

KLUWER ACADEMIC PUBLISHERS

NEW YORK, BOSTON, DORDRECHT, LONDON, MOSCOW 
eBook ISBN: $\quad$ 0-306-48159-6

Print ISBN: $\quad$ 1-4020-0894-5

C2003 Kluwer Academic Publishers

New York, Boston, Dordrecht, London, Moscow

Print @2002 Kluwer Academic Publishers

Dordrecht

All rights reserved

No part of this eBook may be reproduced or transmitted in any form or by any means, electronic, mechanical, recording, or otherwise, without written consent from the Publisher

Created in the United States of America

Visit Kluwer Online at:

and Kluwer's eBookstore at: http://kluweronline.com

http://ebooks.kluweronline.com 
For Kurt,

Scholar, Mentor and Friend

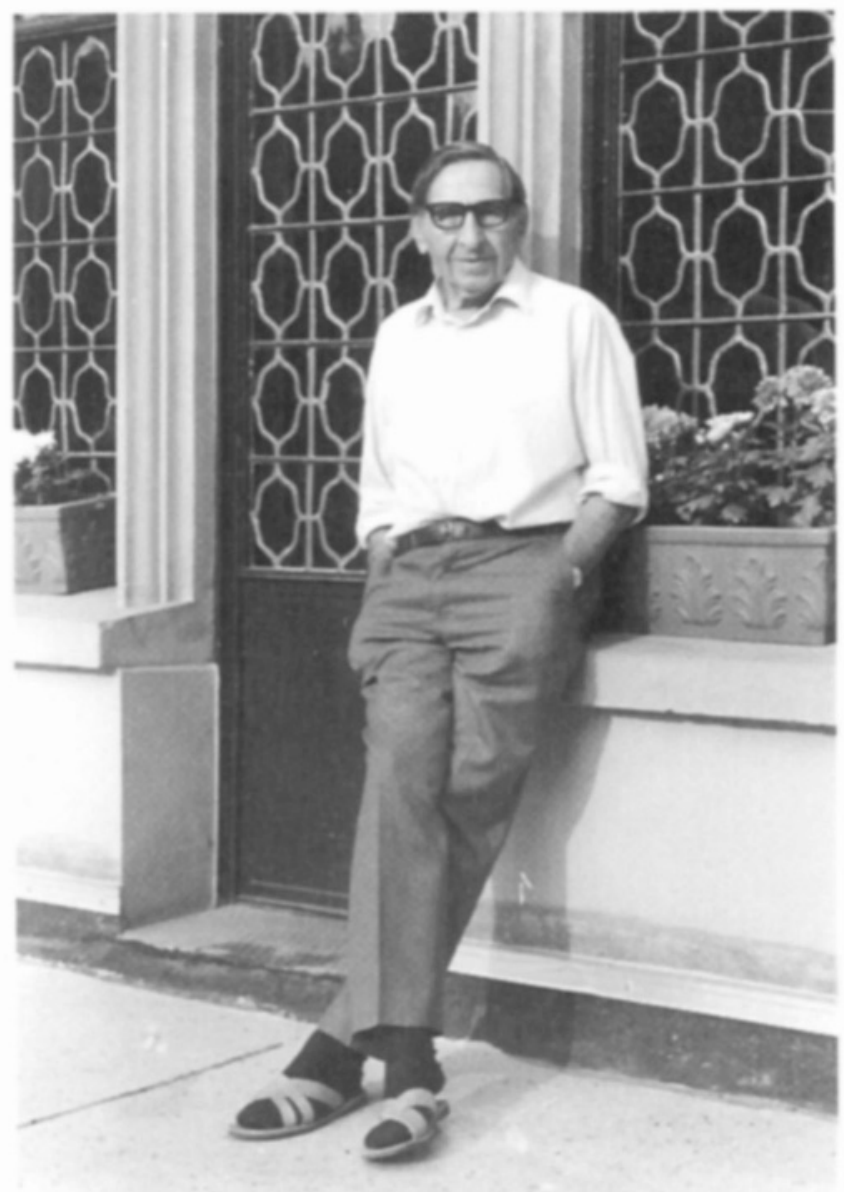




\section{Contents}

Foreword

Jan Pronk

Introduction: Institutions in Modern Development Economics

Valpy FitzGerald

1 Agrarian Reforms and Intersectoral Relations: A Summary

Kurt Martin

Introduction

Economic and social objectives of land reforms

The labour-surplus condition

Conclusion

Notes

References

\section{Bringing Institutions into Evolutionary Growth Theory}

Richard R. Nelson

Institutional analysis and evolutionary economic theory: The historical connections

Routines as a unifying concept

Social technologies and institutions

Institutions in an evolutionary theory of economic growth

Promise and challenges

Notes

References

3 Towards an Evolutionary Economic Approach to Sustainable Development

J. B. Opschoor

Introduction

Ecology and evolution from an economic perspective

Environment-economy interactions and ecological economics

Evolutionary dimensions in ecologically sensitive development economics 
The Environmental Kuznets Curve 36

Conclusions $\quad 43$

$\begin{array}{ll}\text { Notes } & 47\end{array}$

References $\quad 49$

4 Structural Dynamics and Economic Development

José Antonio Ocampo 55

Some methodological issues and stylized facts 56

The dynamics of productive structures 61

A simple formalization of the growth-productivity link 71

Policy implications $\quad 75$

Notes 78

$\begin{array}{ll}\text { References } & 80\end{array}$

5 Economic Reforms, Development and Distribution:

Were the Founding Fathers of Development Theory Right?

Rob Vos $\quad 85$

Introduction $\quad 85$

The move towards liberalization in Latin America 87

Growth, distribution and poverty in Latin America: Recurring problems 90

Conclusions $\quad 96$

Notes $\quad 97$

$\begin{array}{ll}\text { References } & 97\end{array}$

6 Why Groups Matter

Frances Stewart 101

Introduction 101

The nature and functioning of groups 103

Groups: Some examples 107

Some findings and conclusions $\quad 115$

$\begin{array}{ll}\text { Notes } & 119\end{array}$

References 121

7 Rethinking Development Assistance: The Implications of Social Citizenship in a Global Economy

E. V. K. FitzGerald 125

Introduction: The motivations for development assistance 125

The 'incomplete markets' model: Development assistance as a correction for market failure 
The 'human entitlement' model: Development assistance as global social citizenship

Conclusion: Development assistance and international political economy

Notes

References

\section{Partnerships, Inclusiveness and Aid Effectiveness in Africa}

B. J. Ndulu

Introduction: Aid and African growth

Aid effectiveness: What we have learnt from experience

Effectiveness of government as aid intermediary: A conceptual framework

Behaviour of the aid intermediary under a weak authoritarian regime

Unsustainable development autocracy and the seed for a more inclusive governance

Moving more positively into the twenty-first century through a tripartite partnership

Notes

References

\section{Aid, the Employment Relation and the Deserving Poor:}

\section{Regaining Political Economy}

Marc Wuyts

Introduction

From poverty to unemployment: The emergence of a new

The reverse transition: From unemployment back to poverty

From aid as investment support to aid as poverty alleviation

References 


\section{Foreword}

Jan Pronk

The role of institutions in economic development has been debated at length. It is a major chapter in the history of economic thought. It was also a key issue in comparisons of the effectiveness of Eastern and Western economic systems. Understanding the variety of social and cultural institutions has always been crucial in analysing development processes in Africa, Asia, the Middle East and Latin America. Less attention has been given to institutions in studies of the economic performance of Western countries. This may be because economic policies in the West were mostly oriented to the short and medium terms rather than to the long-term perspective. In the short run institutions are given, in the long run they lend themselves for change.

From the outset, economic institutions (e.g. markets, enterprises) and their underlying values (e.g. efficiency, economic freedom) received much attention. Similar attention was given to political institutions (the state, government, the law) and values (democracy, accountability, human rights). Thought also turned to social institutions (entrepreneurship, the middle class, the family household, land-tenure systems) and social values (tradition, gender and age relations, justice). Studies soon followed of cultural institutions (religion, ethnicity) and values (material consumerism or the bond between man and nature). Without the insight gained by studying institutions, economics would have become a dull discipline.

There have been periods in which economists focused so strongly on policymaking that they tended to neglect the role of institutions. In the West, the post-War period of Keynesian macroeconomic policymaking is such a period. In the South, the adjustment years of the 1980s provides a similar example. Both proper management of the business cycle and effective handling of structural imbalances are necessary to restore a path of sustained economic growth. However, both require good insight into the policy environment and thus into institutions. Uniform macro-policies, irrespective of history, culture, ecology and power relations, will fail to bring about stability and growth.

However, it is not enough to simply emphasize the need to change institutions. In the 1990s the emphasis on the need for good governance in developing countries was too general. It was often perceived as foreign pres- 
sure, which met resistance and led to new bottlenecks. After 1989 calls for a quick dismantling of the institutions of the centrally planned economies led to new instabilities. Part of the power shifted to groups who were even less accountable than those they replaced. In the West, the lifting of restraints to market behaviour is freeing the way for corporate greed, proving detrimental to public trust in the system.

Understanding a process of change requires analysis in multiple dimensions. Rendering a policy advice requires specific knowledge of time, place and conditions. What is true or good in one country may turn out to be false or bad in another. What was valid a decade ago may be unreasonable today. Institutions differ and change. This explains why the study of economic development is so attractive and why giving policy advice is such risky business.

Will this be less so in the future? Globalization has lessened the relevance of national frontiers and boundaries between markets. The driving forces behind this process demand more uniformity throughout the world: uniform market standards, uniform good government criteria, uniform legislation, and uniform consumer demand. Globalization means that differences in time and place have lost some of their meaning: the scale of economic operations can be easily overseen wherever one is, and at each moment of time information is available anywhere.

However, even a uniform global process of change will have different impacts in different environments. The large institutional variety at present, both within and between countries, will result in different responses to the call for uniformity. It is not a matter of global technological change simply overtaking national institutional rigidities. Institutions themselves are alive. They are man-made, the result of people's responses to past change. They can be adjusted to new change. Institutions are not the boundary conditions of change, only limiting the capacity for sustainable development. They are the results of change in the past and they sustain other results of that past change. They are also capable of giving further direction to change, partly by absorbing new challenges, partly by resisting them or limiting their effects, partly by canalizing them within society. Institutions can also do this when the driving forces behind new challenges come from outside.

So, globalization does not make the study of institutions less relevant. On the contrary, if we define institutions as ways and means by which people have tried to respond to challenges and master change, studying institutions is all the more relevant the more change (development, growth, progress, conflict, etcetera) is expected.

This book brings together a series of papers on institutions in economic development in honour of Kurt Martin. Kurt Martin (1904-95) was a renowned development economist who remained an active scholar until his death. The study of institutions was a major chapter in his work, a centre- 
piece. He was a pupil of the great classical economists at the turn of the nineteens into the twentieth century, and he lived through that century not only as an observer and analyst but also as an active citizen and a listening teacher. He did not belong to a particular school but he had many students, who were attracted by his capability not only to teach but also to learn, gaining new insights both from other disciplines and from the reality of institutional change. That makes Kurt Martin worth reading at this new turn of the century.

The authors of the papers in this book have done just that. They all benefited from Kurt Martin's contributions to economic thought. The papers contain analyses of change in institutions in different areas of economic development in different parts of the world. To try to understand the workings of institutions - man-made structures that gain a life of their own and thereby a capacity to guide a society - is a rewarding exercise, both for students of development and for policymakers. That makes this tribute volume not only a response to earlier thinking, but also a contribution to new thinking.

Jan Pronk 


\title{
Introduction: Institutions in Modern Development Economics
}

\author{
Valpy FitzGerald
}

This book is based on a special lecture series entitled Social Institutions and Economic Development held at the Institute of Social Studies between 1999 and 2001. Kurt Martin, whose family kindly sponsored the lectures in his memory, was a professor of development economics at ISS in The Hague from 1969 until his retirement in 1985 - although he remained an active influence at the institute until his death in 1995 through both his frequent visits and the activities of the many ISS faculty members who regarded (and still regard) themselves as his alumni.

Born in 1904, Kurt was undoubtedly one of the most significant development economists of the twentieth century, and I was fortunate enough to be the amanuensis for his last book. ${ }^{1}$ From him I began to understand the history of modern economic thought as being about structural transformation, where the trunk passes so to speak from the classical economists of the eighteenth and nineteenth centuries, through Central Europe and Russia in the early twentieth century and on to 'developing countries' in the latter half of the twentieth century. At the opening of the twenty-first century, the study of 'globalization' is the clear successor to this political economy tradition. From this perspective, it could even be argued that the neoclassical model that dominates current economic theory will eventually be seen as a 'deviant branch' from this common trunk.

It is frequently asserted - erroneously - that development economists underestimate the importance of institutions. While this may have been true of certain neoclassical economists, it was not a characteristic of the founding fathers of development economics. ${ }^{2}$ Kurt Martin made institutions a central feature of his own work. He stressed their importance throughout the history of economic theory itself and also in the philosophical foundations of the subject. ${ }^{3} \mathrm{He}$ regarded Schumpeter, who is now considered a key figure in evolutionary economics, to be a dominant influence on early development economists. ${ }^{4}$ Nonetheless, Kurt felt that economic institutions were the result of historically embedded processes of social conflict rather than simply a solution to problems of transaction costs and collective action dilemmas. 
One of his colleagues at Manchester before Kurt came to The Hague was Nobel Laureate Arthur Lewis. Lewis dedicates a substantial part of his extremely influential book, which set the agenda for much of early development practice, to economic institutions. ${ }^{5}$ Three topics that Lewis covers in some depth are 'the right to reward', 'trade and specialization', and 'economic freedom'; all of them very much in the neoclassical tradition of his fellow laureate Douglass North. ${ }^{6}$ However, when Lewis goes on to examine the key 'development' cases of religion, slavery, the family and the organization of agriculture and cottage industry, he approaches an evolutionary definition of the process of institutional change in developing countries not far removed from the political economy of Kurt Martin, whose seminal text on industrialization Lewis freely acknowledges as having influenced his own views. ${ }^{7}$

The current interest in economic institutions is fuelled in part by a reaction to the failed reductionism of monetary stabilization policies and structural adjustment programmes, but also - and more significantly - by the realization that the process of globalization has favoured the countries with institutions most capable of coping with exogenous economic change. A global market has emerged as the result of the progressive liberalization of domestic economies, the diversification of investment and production and technological change. ${ }^{8}$ But the dismantling of old institutions of national economic management (such as planning ministries and state enterprises) is clearly not enough. New institutions are also needed to support not only the market but also social infrastructure and productive learning.

The creation of a global market is, moreover, proceeding at differing speeds. The integration of capital markets is perhaps moving the quickest, but without the strict regulation that characterizes domestic financial markets in order to prevent systemic collapse and protect consumers. Further, there is more or less complete free trade in goods (with the striking exception of farm products) but not in services, because this requires regulatory harmonization. There is also almost complete immobility of labour de jure, even while de facto there are large illegal movements of labour and refugees. Moreover, this global market is without institutions. What appear to be market institutions, such as the World Trade Organization or the International Monetary Fund, are in fact intergovernmental bodies with neither the power to intervene directly in markets nor authority over families and firms. The absence of international commercial law in this context is even more surprising, because throughout the history of capitalism markets have required a legal foundation. ${ }^{9}$

The Kurt Martin Lecture Series brought together a distinguished cast of international experts on social institutions and economic development; to each of these experts an ISS faculty member 'replied' with another paper. 
These papers form the basis for this book. ${ }^{10}$ In addition, I felt it would be appropriate to include an unpublished paper ${ }^{11}$ on agrarian reform by Kurt Martin himself as a prelude, not only because he was the dedicatee of the lectures but also because his paper presents an elegant analysis of the interplay between markets and institutions, which concerns all the following papers. In Chapter 1, therefore, Martin addresses issues raised by the evidence of rural poverty on a large scale and of increasing landlessness in many parts of the developing world, even in countries where economic growth has been impressive by historical standards. He asks to what extent and under what conditions this situation can be redressed by agrarian reform.

Although since his writing (in the 1970s) agrarian reform has gone off the development agenda, so to speak, rural populations have continued to grow and, along with attempts to intensify cultivation, all governments are trying to generate off-farm jobs to absorb the natural increase in the agricultural labour force. However, attempts to combine policies of industrialization with the economic and social objectives of agrarian reform cannot go far or continue for long unless agriculture is producing growing marketable surpluses for sale to the non-farm population. Kurt took up this issue because it arose so often in the history of development and because it forms part of a wider set of problems, including the political demand for access to land, the effects of land reform on agricultural production and the distribution of income and the 'intersectoral' relationship between agriculture and industry. Martin concludes that the extent to which the economic and social objectives of agrarian reform can be attained within the framework of private ownership of land depends largely on the success of policies to hasten the end of the labour-surplus condition.

In Chapter 2, Richard Nelson of Columbia University picks up the tradition of evolutionary economic growth theory as a critique of neoclassical theory, which is 'blind' to technical progress and neglects the role of national systems of innovation as expressions of conscious human action. Nelson suggests that the Schumpeterian tradition of evolutionary economics is gradually converging with institutional economics as pioneered by John Commons and, more recently, theorised by North, the former by exploring technological change and the latter by addressing human interaction. Institutionalists could learn from evolutionary economists' understanding of pathdependency; while evolutionists could learn from the institutionalists' formal analysis. Nelson suggests that one way to approach such an integration of ideas is through the notions of 'productive routines' and 'social technologies' which characterize effective ways of solving problems so that institutions can be seen as supportive to rather than as 'constraints' on economic agents in the market. The nineteenth century development of both mass-production manufacturing in the United States and the synthetic dyestuffs industry in 
Germany neatly illustrates Nelson's argument. In sum 'physical and social technologies co-evolve'.

Nelson's is an essentially benign view of economic progress - at least in the advanced countries. While recognizing the need for collective action, it does not examine the political interests that might promote or thwart such action. As Martin's own essay in this volume indicates, the choice of both physical and social technologies (i.e. agricultural mechanization and land tenure) reflects the relative power of rich and poor and may affect both the progress of industrialization and the incidence of poverty.

In Chapter 3, Hans Opschoor explores the ecological aspects of development from an explicitly evolutionary perspective and radically widens the agenda set out by Nelson. Opschoor argues that development occurs on the basis of activities involving both the natural and the social spheres, and it involves notions such as learning, anticipation, positive externalities and feedback. The present rector of the ISS suggests that a reformulation of development theory could fruitfully draw on both ecological and evolutionary economics. The issue of the link between economic growth and environmental degradation is a good example: sustained economic growth is not necessarily environmentally sustainable, nor will it automatically become sustainable. Sustainable development is most likely to be the reflection of deliberate environmental and developmental policies and policy-induced technological as well as institutional innovations.

In a wider sense, Opschoor argues that development takes place in a world in which adaptations and options are a matter of human design and societal implementation - in a more or less rapid, potentially goals-oriented and cumulative way. According to Opschoor, even values and preferences and changes in them over time can be analysed and understood through evolutionary methods. A perceptive analysis of the recent debate on the 'Environmental Kuznets Curve' underpins Opschoor's argument; although he does not remark on the fact that while the original Kuznets model was based on intuition rather than evidence, ${ }^{12}$ it was at least soundly derived from the accepted concept of the changing balance of labour allocation between agriculture and industry. The 'environmental' version in contrast seems to rely on little more than the notion of pollution as an inferior good.

Opschoor concludes that addressing such issues requires an advance in analytical and anticipatory capacity so as to enable society to better understand and predict society-environment interactions and co-evolutionary change. He proposes a move towards integrated modelling and theory building that would include relevant parts of the ecological systems in which economic processes are embedded. In sum, development economics must open up to ecological as well as evolutionary approaches rather than rely upon the sub-discipline of 'economics' alone. 
Although Kurt himself put little weight on environmental issues, ${ }^{13}$ he would have been pleased with the way that Opschoor incorporates the views of the classical economists into the current concerns of environmental economics. However, the idea that the 'natural sphere' has its own dynamic would have appeared strange to him ${ }^{14}$ - Darwinian at best and at worst a hangover from the Physiocrats. Nonetheless, economists whom Kurt admired, from Alfred Marshall to Ester Boserup, have argued persuasively that an ecological approach is a useful way to capture the dynamic relationship between conscious humanity and the natural world. Indeed, the contemporary concept of 'sustainable development' clearly relates the notion of 'development' to rich as well as to poor countries.

Kurt Martin always saw economics as a tool for bettering the human condition in general and for reducing poverty in particular. It is in this spirit that in Chapter 4, José Antonio Ocampo argues that recent contributions to economic thinking have provided useful means for understanding the frustrations that trends in policy-making have generated and, in turn, provided a basis for alternative policies to promote economic growth. The current Executive Secretary of the UN Economic Commission for Latin America and the Caribbean, Ocampo starts by looking at methodological issues and 'stylized facts' on growth and distribution in developing countries, drawing basically from the Latin American experience. He then turns to the dynamics of changing structures of production. Afterwards, Ocampo sets out a simple yet persuasive model of the linkages between such dynamics and overall economic and productivity growth from which he draws significant policy implications.

At an analytical level, Ocampo draws extensively from both the new and the old development literature to elucidate the central theme that growth is intrinsically linked to the dynamics of productive structures and to the particular institutions that are created to support it. The mix of dynamic productive structures and a supportive macroeconomic environment are, in this interpretation, the key to successful development. While the broader institutional context and the adequate provision of education and infrastructure are essential background conditions, they do not generally play a direct role in determining changes in the momentum of economic growth. The two crucial services that institutions provide are reducing information costs and solving the coordination failures that characterize interdependent investment decisions in a market economy.

His might thus seem to be an 'anti-institutionalist' view, except that his own outstanding work on the economic history of Colombia and on macroeconomic management in Latin America proves otherwise. Rather it is a question of whether it is the institutions as such or the policymakers within them (national, but also international), and the economic doctrines they es- 
pouse, that actually determine outcomes. The assumption that dynamic productive structures, and the particular institutions that support them, are the automatic result of market mechanisms in general and of the integration into the world economy in particular is demonstrably false - in the case of Latin America at least, according to Ocampo's persuasive argument. This view that directed state intervention is necessary in order to achieve economic development is one which Kurt Martin supported. Indeed,

[t]oday, in spite of the sophisticated analytical techniques, and often highly esoteric specialisms characterising late twentieth-century economic science, the primary object of the exercise remains the same as it was in the seventeenth century: to provide national administrators and their responsible agents with the objective knowledge required to design and implement efficient economic policies (Deane 1989: v).

This theme of the conditions needed for sustainable economic growth in Latin America is continued in Chapter 5 by Rob Vos, currently deputy rector of the ISS. Vos points out that 'founding fathers' of development economics such as Paul Rosenstein-Rodan not only regarded exports as central to growth (they were thus not strict adherents to import substitution as their critics held) but they also saw export growth as more than a problem of overcoming low income elasticities of world demand. The more important point was the need to create technological externalities (such as 'learning by doing' and adequate social overhead capital) even in an open economy. In today's language, the core of endogenous growth capability is whether an economy possesses adequate infrastructure, human capital and entrepreneurial skill (including workers' learning by doing) to take advantage of opportunities provided by the global economy. Having put it this way, Vos is perhaps justified in asking, "What's new about the new growth theory?"

Vos nonetheless recognizes that the policy environment has changed dramatically since the post-War decades when development economics was first established. The founding fathers saw economic planning, aid and trade protection as important instruments to overcome the perceived development bottlenecks. Today's conventional wisdom is that globalization and free flows of commodities and capital are the prime movers of growth and development. However, summarizing his own careful quantitative research conducted in a large number of Latin American countries, Vos asserts that economic liberalization during the past three decades has not in fact brought the type of 'Big Push' that its advocates hoped for. Further, this 'post-modern' growth process seems to have exacerbated inequality rather than resolved it. In other words, institutions must be constructed not only to make production and investment more efficient, but also to reduce inequality and mass poverty if the resulting growth is to be sustainable. Needless to say, 
this view is entirely consistent with Kurt Martin's own view of the central dilemma of development.

Institutions are inhabited by people, not just individuals but also by groups of people bound together by various socially constructed ties. In Chapter 6, Frances Stewart of the University of Oxford provides an overview of the role of 'groups' with economic functions in development, drawing on both neoclassical and communitarian views. Her purpose is to explore different types of group behaviour and to identify reasons why some groups appear to work better than others. Given that humans invariably operate in groups, group behaviour is a systemic phenomenon which we must explore if we are to understand development. After defining some suitable categories for classifying group behaviour, Stewart presents case studies of public sector and community groups, contrasting successes and failures in several areas. The argument she advances does not intend to deny the important role of the market in resource allocation and innovation. Rather it emphasizes that collective action also has a critical role to play in development. If collective efforts are undermined by the norms promoted as a result of the enlarged role for the market and a diminished role for government, groups will still emerge but they will become more destructive than constructive of development.

Stewart regards groups as having both efficiency and claims functions: norms matter as well as the immediate interests of group members. Group behaviour is based on three models: power and control, incentives, and long-term reciprocity. The originality of Stewart's approach is the contention that group motivations are socially constructed and an essential part of the development process. They therefore cannot be reduced to contractual arrangements between members. The examples given, oriented logically enough to the resolution of poverty, are of cooperative ventures at the local and micro level and provide stimulating insights.

An institutional 'triad' of households, firms and governments forms the basis of modern economic theory. Each element has distinct objectives, constraints and powers: households save, consume, provide labour; firms invest, produce and employ labour; governments regulate the market, provide infrastructure and redistribute income. An essential part of the neoclassical project is to deny this institutional system: firms are reduced to extensions of shareholders' desires through the 'corporate veil'; families are seen as contractual arrangements between members; and governments are at best providers of services to voters and at worst a vehicle for achieving the personal aims of state elites. This seems to be essentially misguided, as Stewart's 'group principle' makes clear. Nonetheless, it is still far from clear why this triad of household, firm and government is so durable and why other types of group are so unstable. 
In Chapter 7, FitzGerald ${ }^{15}$ addresses the emerging model for development assistance in the new century on the assumption that the full integration of developing countries into the global economy requires correcting for failures in product and factor capital markets. 'Aid' as such would be confined to humanitarian emergencies and activities with large international externalities. However, without free labour movement, the logical implication of this approach is that citizenship itself becomes an economic asset. This model contrasts starkly with a second model: the notion of development assistance based on resource transfers to the most vulnerable countries or social groups as a form of 'social entitlement' in a global market. People's right to a minimal social entitlement can be derived from accepted principles of the theory of justice and are implied by international law. However, this model of global social citizenship also logically implies a corresponding system of international taxation. Despite the dominance of the first model due to the present geopolitical balance (or rather imbalance) of power, some trends in international political economy - such as repeated financial crises and outbreaks of armed conflict - may favour emergence of the second.

The difficulties of collective action, of how to form an effective regulatory grouping as a prelude to global institutions, are basically ones of political economy. Institutional economics does not provide us much help in resolving them. Even the meta-theory of foundational social contracts in the tradition of modern liberal political philosophy is not very useful. Indeed John Rawls' indifference principle is explicitly held to be inapplicable to global institutions - basically because the citizens of rich countries do not recognize the vast majority of the world population as party to a social contract that underpins the global economy. ${ }^{16}$ While nation-states are founded on political constitutions, there is no international equivalent of their constitutions; even the United Nations is an inter-state body.

Inter-state relations between developed and developing countries are exemplified by the institutional structure of what is optimistically known as 'development cooperation' and more commonly as 'aid'. In Chapter 8, Ben Ndulu of Tanzania examines the reasons behind the poor record of aid effectiveness in Africa with particular focus on aid relationships as the key influence. His main hypothesis is that aid can be more effective if there is greater inclusiveness in the design and execution of aid programmes and strong citizen voice as a mechanism to enforce accountability and commitment to results. Ndulu reviews wisdom gleaned from his long and broad policy experience in Africa on what matters most for aid effectiveness. This leads him to propose a conceptual framework for an effective aid relationship based on effective accountability systems for achieving the results desired and for enforcing broad-based preferences. 
However, if the proposed 'partnership approach' to aid relationships is to have any real meaning, other than as a public relations gloss on traditional inter-state dependence, then this framework must be implemented by donors in the conscious realization that they will have to cede power in exchange for effectiveness. Operationalizing a partnership approach will be far from easy, although Ndulu makes some valuable suggestions on how it might be achieved. In particular, he stresses the need for an explicit contractual relationship between donor and recipient, greater transparency and participation in the negotiation process and institutional reform in the private sector (both non-governmental organizations and business) as well as in the public sector. This is not only a matter of ensuring more efficiency and less waste, but also of generating a stronger political constituency for sustained development.

Ndulu's is still a relatively 'instrumental' view of the operations of aid institutions; it assumes a common view of objectives and thus a shared economic discourse. However, as Kurt Martin frequently pointed out, such assumptions should never be taken for granted. In Chapter 9, Marc Wuyts of the ISS explores what he terms the historic conceptual reversal in economic discourse 'from poverty to unemployment' then 'from unemployment back to poverty'. He links this latter transition with its accompanying changing emphases in foreign aid - that is, with the transition from aid as investment support to aid as poverty alleviation. Wuyts argues that the reversal from 'unemployment back to poverty' needs to be situated within the broader process of a 'spiral reversal' in capitalist development from the 1980s onwards. The approach adopted in this chapter, like that of Kurt Martin himself, is rooted in classical political economy and thus is a fitting closure to the volume. Wuyts draws inspiration not only from the literature of the early pioneers of development economics (including Kurt Martin himself) and the debates surrounding aid and structural adjustment policies, but also from the recently emerging literature on the history of the theory and practice of social statistics.

Wuyts reviews the earlier transition from poverty to unemployment as the central concern of economic discourse for public policy, in England in particular and in the industrialized world in general, during the late nineteenth and early twentieth centuries. He then turns to development economics proper and looks at the reverse transition from unemployment and absorption of the labour surplus to poverty as the key concern of economic policy in developing countries in the late twentieth century. Wuyts concludes by suggesting that the changing emphases in foreign aid - the transition from 'aid as investment support' to 'aid as poverty eradication' reflects a broader process of transition from the centrality of the employment relation back to poverty. 
Kurt Martin reflected in his own life the grand tradition of European social thought since the Enlightenment, the contradictory combination of economic rationality, humanism and the desire for justice. ${ }^{17}$ He was a natural socialist, but already highly critical of 'actually existing socialism' in the early years of the last century. The demise of explicitly socialist states at the end of the century was nonetheless a disappointment because he held that modern civilisation should be based on the principles of cooperation rather than those of competition. Capitalism, however productive and even creative, is also unjust and wasteful, and thus ultimately irrational. In this sense Kurt was very much a modernist child of his time, a pre-1914 economist. He never became a post-modernist and was justifiably proud of having belonged to the early Frankfurt School of political economy rather than the later - and more famous - school of critical theory.

These lectures - and this book - thus continue the kind of debate that Kurt used to enjoy on the themes he thought were important. In the best sense, therefore, this is a fitting tribute to an extraordinary man, an influential scholar and a much-loved friend. Nonetheless, I am sure that had he been here for these lectures, he would have pointed out, as he so often did in the coffee room of Die Wittebrug, politely yet firmly that all of our eloquent theorising about institutions and economic development had already been said "so much more clearly by Ricardo and Marx".

\section{Notes}

1. That is, Martin (1991).

2. See the introductory chapter of Cooper and FitzGerald (1989).

3. He always recommended Schumpeter on the history of economic thought (Schumpeter 1954) to students, although he himself preferred Lowe on economic epistemology (Lowe 1965).

4. Particularly Schumpeter (1934) originally published in German in 1912, rather than the better-known Schumpeter (1942) to which evolutionary economists usually refer.

5. Lewis (1955) Part III.

6. For instance, North (1990) sees the 'demand for' and 'supply of institutions interacting in a progressive manner over time.

7. Mandelbaum (1945).

8. Turning the end of the Cold War into a historical time warp, as if we were leaping backwards to 1914 . 
9. See Chapter 8 in this volume.

10. Refer here to the 'le Nez' lecture and the Saith reply; neither were written up and thus are not in this volume.

11. In fact this paper initiated the well-known ISS Working Papers Series in 1981.

12. As Martin (1991: 47) points out.

13. "Ecology as far as I can see has been neglected. An Indian author once said that poverty is our real pollution" (Martin, 1991: 52).

14. Unfortunately they did not have the opportunity to debate these issues.

15. As editor, I have to adopt the rather contrived position of referring to myself in the third person. Kurt Martin had the advantage of being able to refer to himself as 'Mandelbaum' when writing about his earlier work.

16. See Rawls (1999) for instance; although he overlooks the fact that the citizens of developing countries are offered little choice as to the rules upon which they wish the world economy to be organised. But then the slaves had little input to the US constitution either.

17. For a short intellectual biography, see my essay 'Kurt Mandelbaum and the Classical Tradition in Development Theory' which provides the opening chapter to Martin (1991).

\section{References}

Cooper, C. and E. V. K. FitzGerald (1989) Development Studies Revisited: Twenty-Five Years of the Journal of Development Studies. London: Cass.

Deane, P. (1989) The State and the Economic System: An Introduction to the History of Political Economy. Oxford: Oxford University Press.

Lewis, W. A. (1955) The Theory of Economic Growth. London: George Allen \& Unwin.

Lowe, A. (1965) On Economic Knowledge: Toward a Science of Political Economics. New York: Harper \& Row.

Mandelbaum, K. (1945) The Industrialization of Backward Areas. Oxford: Blackwell.

Martin, K. (ed.) (1991) Strategies of Economic Development: Readings in the Political Economy of Industrialisation. Basingstoke: Macmillan.

North, D. (1990) Institutions, Institutional Change and Economic Performance. Cambridge: Cambridge University Press.

Rawls, J. (1999) The Law of Peoples. Cambridge, MA: Harvard University Press.

Schumpeter, J. A. (1934) The Theory of Economic Development. Cambridge: Cambridge University Press.

(1942) Capitalism, Socialism and Democracy. New York: Harper \& Row. (1954) History of Economic Analysis. New York: Oxford University Press. 